\title{
近世城下町における山当てとヴィスタの実態に関する研究
}

新潟県村上市を対象として

\section{A STUDY ABOUT THE ACTUAL CONDITION OF “YAMA-ATE” AND VISTA IN CASTLE TOWN}

Murakami city in Niigata Prefecture as study object

\author{
菅野圭祐 ${ }^{*}$, 佐藤 滋**
}

Keisuke SUGANO and Shigeru SATOH

\begin{abstract}
The castle town cities, Yama-ate and Vista, refer to Donjon, Turret and the surrounding mountain peaks, which provide people perpetually changing views, applying GIS to analyze the actual landscape condition of Murakami city, Niigata.

First, It aims to restore the mid-Meiji streets tracing back to the feudal and the Castle, measuring the micro-topography.

Second, Classify the streets into four unobstructed views basing upon street patterns and the appearance of objects, and specify the object mountain.

Third, Analyze these four by street condition, Object Mountain and topography.

The characters of relationship among landscape composition, objects and their locations, can be manifested.
\end{abstract}

Keywords : Premodern City, Urban Design, Urban Structure, Natural Landscape 近世都市，都市設計，都市構造，自然景観

\section{1.はじめに}

\section{1-1. 研究の背景と目的}

我が国の城下町都市では、著者らがこれまでの研究1),2),3),4),5)で示 したように、周辺の山々と平山城の天守・櫓に対する見通しや見え 隠れの風景を各地で多様に観察することができる。また、宮本によ る一連の研究(6) では、象徴としての城郭を際立たせるために、天守 や櫓に対するヴィスタが演出されたことが述べられている。さらに、 桐敷 ${ }^{7,}, 8,{ }^{2}$ ( は江戸の通りの軸線が富士山、筑波山、湯島台などの山 頂へ向かっていることを述べている。

このような現象は、日本及び東アジアの国々で確認され、周囲の 自然環境と一体となった文化や生態学的秩序に関連した都市設計の 方法であったと考えられる。これらは、例えば、山頂を測量の基準 とした実用的なもの、山への眺望をデザインしたもの、逆に山城な どからの街への見通しを作ったもの、さらには、神体山など聖なる 場への信仰軸を作るものなど、意識的に計画されたものと、地形条 件一の自然な応答によって出来た自然発生的なものとに大別される と考えられる。しかし、これらは仮説であり、前者の計画意図は証 明されていない。注1)

こうした計画上の意図を考察するために、山当てやヴィスタの詳
細な実態を客観的に解析する必要がある。そこで本研究では、これ までの研究をもとに、城下町の各地点や街路上の移動に伴い観察で きる景観について、これらが最も顕著に確認される都市の一つであ る村上を対象とし、以下の三点を目的とする。第一に、GIS を用い て藩政末期と街路構成にほとんど変化のない明治中期頃の市街地構 成注 2) の復元を行い、正確な街路形状を把握寸る。これを用いて移 動に伴う山頂及び天守・櫓(以下、「目標物」) の見え方の変化を解 析し、現場の目視では把握の難しい微細な景観特性の違いから、類 型化する。第二に、文献調査により街路の立地条件や対象山の意味 を詳細に把握し、GIS を用いた微地形の計測により、傾斜地や微高 地などの地形条件を正確に把握する。第三に、景観特性の類型と街 路の立地条件、対象山、地形条件の関係を分析する。

\section{1-2. 研究の方法 (図1)}

本研究では、GISシステム (「ArcGIS for Desktop 10.0 (ESRI社製)」) を用いて、以下の方法で分析を進める。第一に、明治中期頃の市街 地構成と、城下域から眺められる目標物の位置を復元し、微地形を 計測する。第二に、目標物を見通すことのできる街路 (以下、「見通 し街路」)を特定し、街路形状と目標物の見え方の関係から4つの類 型を抽出するとともに、目標物の位置する山(以下、「対象山」)の 
特徴を把握する。第三に、4つの類型ごとに、1)街路の立地条件、2） 対象山、3) 地形条件、の3つの分析軸との関係から特徽を分析する。

\section{$1-3$. 既往研究}

天守や櫓に対するヴィスタに関しては、宮本 ${ }^{6)}$ の研究がある。ま た、高見 ${ }^{(0)}$ は、天守や櫓、門、社寺などの配置方法と町割りの方法 に、曲尺の表目と裏目で作る三角形の比率が用いられたことを示し ている。山当てに関しては、桐敷 ${ }^{7), 81,99}$ による江戸、駿府の研究、 揚村・土田 ${ }^{11}$ らのグループによる薩摩外城における一連の研究があ るが、いずれも大縮尺の地図上で平面的な関係を指摘しているのみ である。これに対し、街路と山頂の位置関係を正確に計測した佐藤 $ら^{1), 2), 3)}$ の研究があるが、一定の視点場からの計測であり、移動に 伴う山頂位置の変化や微地形の解析は行っていない。趙ら ${ }^{12)}$ は「景 廊」という概念を用いて、周囲の山と街路の動的な関係を示してい るが、現場の目視によるものであり、藩政期の骨格を復元して行う 正確な計測に基づく分析ではない。これに対し本研究は、GIS上の正 確な座標上に、藩政末期と街路構成にほとんど変化のない明治中期 頃の市街地構成を復元し、街路形状や移動に伴う目標物の見え方の 変化と、地形条件を詳細に解析している。

\section{1-4. 研究対象地}

村上市は、新潟県の最北部で山形県と隣接する人口 6.4 万人 (平成 26年）の都市であり、その歴史的中心市街地は、近世城下町として 形成された。

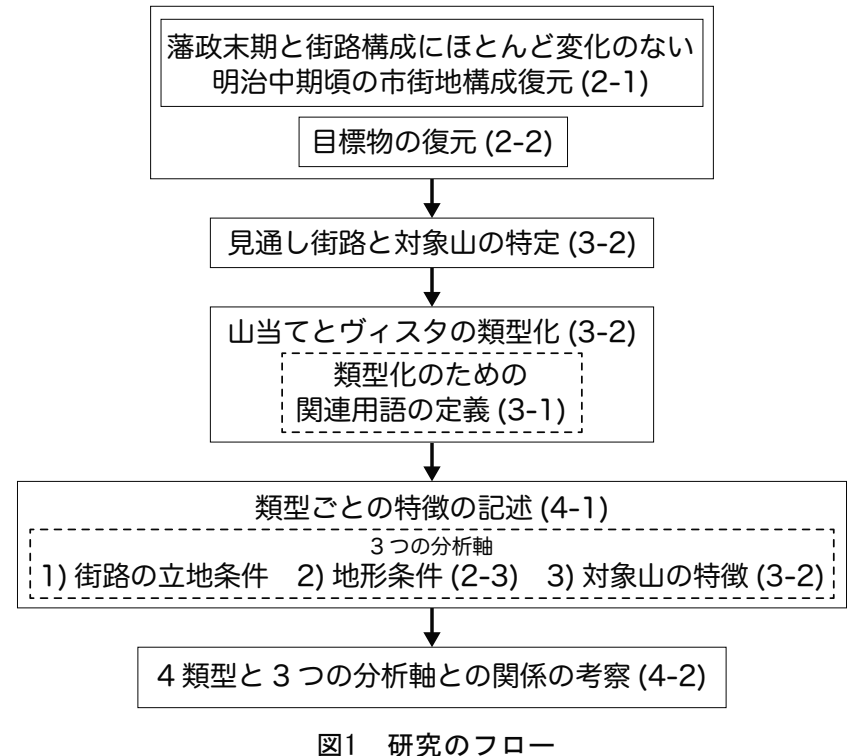

\section{GISを用いた明治中期頃の街路形状、目標物、微地形の再現}

本章では、まず、明治中期頃における市街地構成の復元方法を述 べる。次に、城下域から視認可能な目標物の復元方法を述べる。最 後に、傾斜地と微高地形状の特定方法を述べる。

\section{2-1. 明治中期頃の街路復元 (図2)}

まず、以下の二種の資料を用いて、明治中期頃の街路を復元した。

第一に、旧城下域で昭和 50 年 $~ 57$ 年に行われた、国土調查法に基 づく地籍調査の際に作図された「調査図」である。これは、法務局 に備え付けの公図 (旧土地台帳附属地図)を基盤として地籍調查の結 果を記述した図である。公図に記載の街路構成が赤色（以下、「赤
道」)で示されており、公図の作成年代以降、市が買収して拡幅した 街路の敷地面積が示されている。一般的に、公図は、明治18～21年 に作図された更正地図が主体となっており、注4) 村上の公図につい ても作成年代は同時代であると推察される。注5) これを基盤としたた め、調查図の精度は地籍図と比較して低い。また、縮尺は $1 / 600$ のも のが多いが、公図の縮尺に準じて様々である。

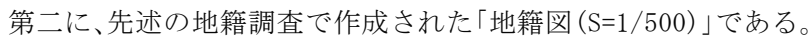
現地測量に基づいており、現場での再現性が高い地図であるが、地 籍図作成時点で市が買収済みの拡幅部分については、拡幅前の道路 幅を示す地割線が消えている。

以上を用いて、赤道の街路線をGISの正確な座標上に復元する。公 図は、明治中期頃までに作成されたと推察されるため、本研究では、 明治中期頃の街路線を復元したものとして扱う。1）地籍図を世界測 地系、平面直角座標系第8系で定義されたArcGISの座標上に重㸚合わ せ、2）地籍図に記載された拡幅前の地割線が赤道の街路線を示して いる場合は、これを明治中期頃の街路線と寸る。3) それ以外は、調 查図に記載の買収済み敷地面積から拡幅幅を算出した。この数値か ら赤道の街路線を作図し、明治中期頃の街路線とする。

尚、赤道の街路構成と内藤信民城主時代 (1785 1800年)の村上城 下絵図注6) を比較したところ、12箇所の柝形に新設道路が通されてい ること、4本の街路形状が変更していること注7) 以外には、大きな変 化がないことがわかった。このため、本研究ではこれらを分析対象 から外し、注8) 対象とする街路については、全て藩政末期と変化のな い街路構成を復元できたと考え、これを用いて見通し街路と対象山 の特定を行うものとする。

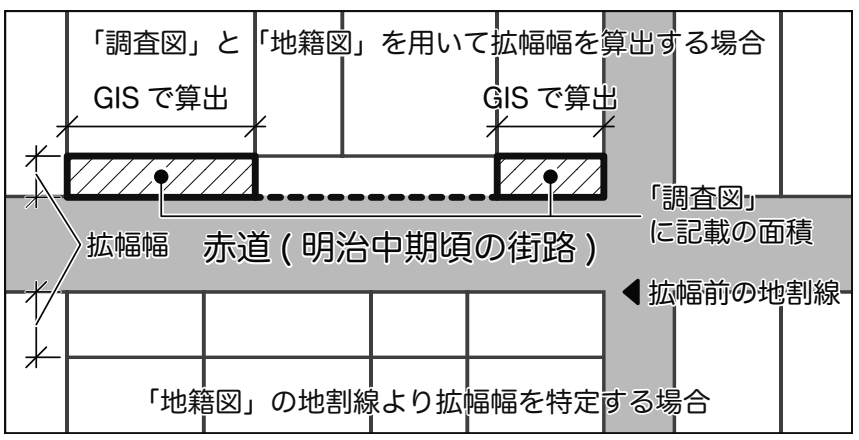

図2 明治中期頃の街路復元方法

\section{2-2. 城下域より視認可能な目標物の位置の特定}

次に、以下の方法で城下域より視認可能な目標物を特定した。 第一に、山頂の特定方法である。国土地理院発行の「数值標高モ デルJPGIS (GML) 形式10mメッシュ」を用いて、城下域からの可視域全 体の数值標高モデルを作成した。これによって城下域から視認可能 な山頂の位置を特定でき、この近辺で最も標高の高い点を山頂とし た。ただし、近傍に地形学上の山頂注9) が設定されている場合は、こ れを山頂とした。なお、視点場によっては、特定された山頂が不可 視であり、他に見かけの山頂が存在することがある。この場合、各 街路中心点から山頂近辺の $10 \mathrm{~m}$ メシュへの仰角を測定し、最も数值 の大きい点を見かけの山頂とした。

第二に、村上城の天守及び櫓の特定である。ArcGISの幾何補正機 能を用いて「史跡指定地整備計画図」注10) を座標上に重衫合わせ、 
各構築物の位置を特定した。標高は、各構築物高さ注11) と最近傍の $5 \mathrm{~m}$ メシュ数值を足し合わせて求めた。

\section{2-3. 微地形の計測による地形条件の特定}

最後に、以下の通り、微地形の計測を行い、傾斜地と微高地の形 状を特定した。

第一に、ArcGISの3DAnalystツールを用いて、5mメッシュの標高デ 一タから傾斜角を計測した。第二に、村上の城下域で、坂と名のつ く街路を特定し、注12) 傾斜角と比較したところ、全て $2.0^{\circ}$ 以上の傾 斜角を持つ地形上に位置していることがわかった。そこで、2. $0^{\circ}$ 以 上を傾斜地とし、特に $3.0^{\circ}$ 以上を急傾斜地とした。それ以外を平坦 地とした。第三に、3DAnalystツールを用いて $5 \mathrm{~m}$ メッシュから $1 \mathrm{~m}$ 間隔 の等高線を作成し、微高地の形状を特定した。

\section{3. 藩政期における山当てとヴィスタの特定と類型化}

本章では、まず、見通し街路の特定方法を確立し、街路形状や目 標物の見え方の違いから類型化するために、用語の定義を行う。次 に、街路形状と目標物の見え方によって見通し街路の違いを定義す る。最後に、見通し街路を特定し、後述のように、4つに類型化する。 また、目標物の位置する対象山の特徵を把握する。

\section{3-1. 街路形状と目標物の見え方による見通し街路の類型化 (図3)}

第一に、見通し街路の特定方法を確立し、街路形状や目標物の見 え方の違いから類型化するために以下の通り、用語の定義を行う。 1) 街路中心点 : $5 \mathrm{~m}$ 間隔で設定した復元街路の中心点。

2) 街路中心視点場 : 沿道に町家の連続する町人地では、視線高さ $1500 \mathrm{~mm}$ から見て、目標物への仰角が町家の軒及び棟に対する仰角よ りも大きく、建物との関係で目標物を見通すことのできる街路中心 点。注 13 ) 町人地以外では、屋敷が道から後退して配置されているた め、建物との関係ではなく、ライン間角度を5m間隔で測定し、注14) 絶対值が $5^{\circ}$ 未満で目標物を見通寸街路中心点。注15)

3) 始点 $\langle s\rangle$ : 同一の目標物に対する連続した街路中心視点場の始点。 4) 終点 $\langle e\rangle$ : 同一の目標物に対する連続した街路中心視点場の終点。

5) 見通し街路 : 始点〈s〉 から終点〈e〉までの街路で、連続して同 一の目標物を見通すことのできる街路。

6)目標ライン：各街路中心点と目標物を結んだ線。

7) 街路両側端視認限界点 (各街路中心視点場に対応)：移動する各街 路中心視点場のそれぞれにおいて、連続して街路の両側端が視認で きる限界の位置での街路中心点。

第二に、街路形状によって見通し街路を以下の通り、類型化する。 8) 直線見通し街路 : 始点 $\langle\mathrm{s}\rangle$ から終点〈e $\rangle$ まで移動する際、街路 両側端視認限界点が変化しない見通し街路。

9) 非直線見通し街路：始点〈s〉 から終点〈e $\rangle$ まで移動する際、街 路両側端視認限界点が変化する見通し街路。

10) 鍵型見通し街路 : 鍵型街路上で一つ目のクランクを曲がった先、 もしくは二つ目のクランクを曲がった先に位置する見通し街路。

第三に、目標物の見え方によって、見通し街路から目標物を見通 す状態を以下の通り、類型化する。

11) 正面に見通す:街路両側端視認限界点での街路幅員に目標ライン が収まる状態。

12)ずれて見通す:街路両側端視認限界点での街路幅員に目標ライン が収まらない状態。
以上を踏まえ、街路形状と目標物の見え方から、山当てとヴィス タについて、以下の4類型を抽出する。

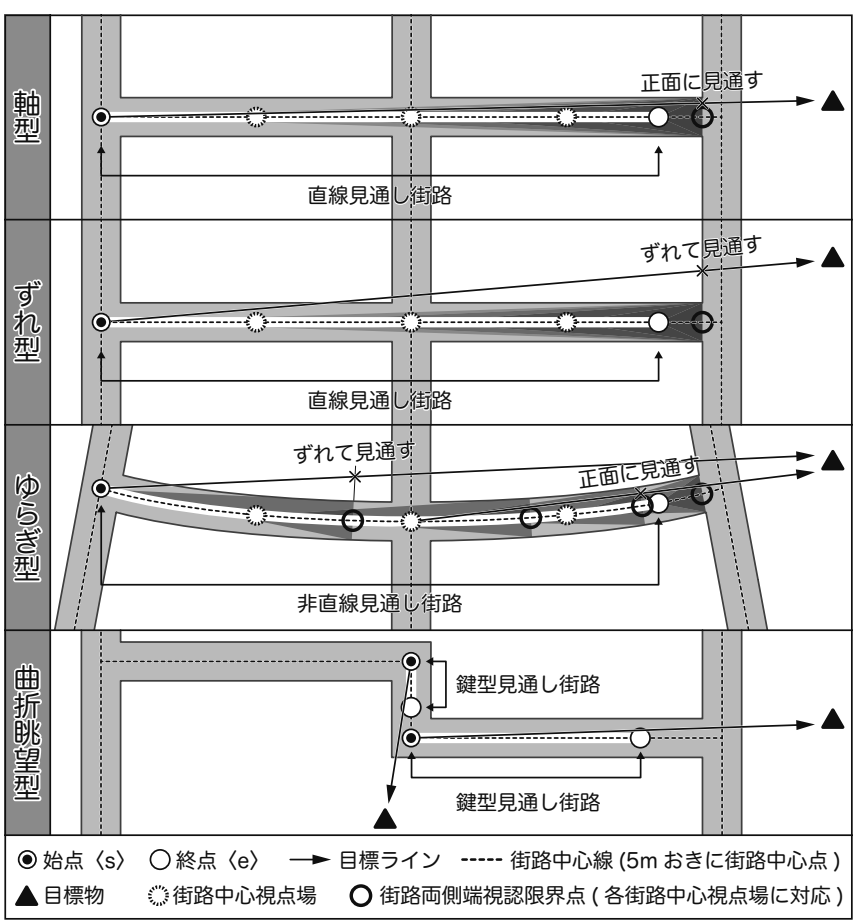

図3見通し街路の4類型

13）軸型見通し街路（以下、「軸型」）：直線見通し街路のうち、始 点〈s $\rangle$ から終点〈e $\rangle$ まで目標物を正面に見通す見通し街路。見通 し街路の正面で目標物が象徵的に見通される。

14)ずれ型見通し街路（以下、「ずれ型」）：直線見通し街路のうち、 始点〈s〉で、ずれて見通す見通し街路。町並みを超えて目標物が借 景的に見通される。

15）ゆらぎ型見通し街路（以下、「ゆらぎ型」）：全ての非直線見通 し街路。始点〈s $\rangle$ から終点〈e 〉に移動する際、目標物を正面に見 通す街路中心視点場とずれて見通す街路中心視点場がある。注16)移 動に伴い、目標物の位置が変化しながら見通される。

16) 曲折眺望型見通し街路（以下、「曲折眺望型」）：全ての鍵型見 通し街路。屈曲の先の視界が開けた空間で目標物が見通される。

\section{3-2. 見通し街路と対象山の特定}

以上の方法で全街路中心点と全目標物に対して測定を行ったとこ ろ、76本の見通し街路が特定でき、軸型が8本、ずれ型が4本、ゆら ぎ型が54本、曲折眺望型が10本となった。また、目標物は下渡山山

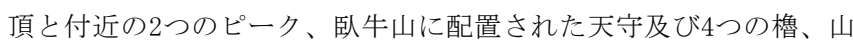

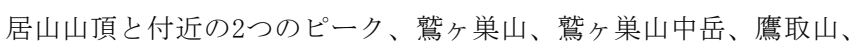
虚空蔵山、名称不明山のそれぞれの山頂、計16であった。特定され た7つの対象山の特徴を以下に述べる。（図4）

1)下渡山

城下の北に位置する、なだらかな山容の山で、山頂 (標高 $237.8 \mathrm{~m}$ ) の他に下渡山 (西a) (標高 $242.6 \mathrm{~m}$ ) と下渡山 (西b) (標高 $217.1 \mathrm{~m}$ )の二つ の顕著なピークが見通される。瀬波郡絵図に「下渡ヶ嶋古城」の記 載があるように、村上城の付城として中世に下渡嶋城が築かれた。 
注17) 下渡山を対象山とする見通し街路は計13本で、これらの街路の

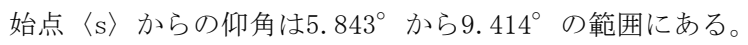

2) 臥牛山

城下の東に位置する、なだらかな山容の山で、16世紀中頃から末 にかけて本庄繁長によって城塞が築かれ、その後村上氏、堀氏によ つて近世城郭に改造された。注18)城下より明確に見通される構築物 は、南から天守 (標高 $154.5 \mathrm{~m}$ )、出櫓 (標高 $124.1 \mathrm{~m}$ )、東多門 (標高 118. $4 \mathrm{~m}$ )、四ツ門 (標高 $108.6 \mathrm{~m}$ )、勒櫓 (標高 $105.1 \mathrm{~m})$ の五つである。臥 牛山を対象山とする見通し街路は計 22 本で、これらの街路の始点 $\langle\mathrm{s}\rangle$ からの仰角は $3.308^{\circ}$ から $21.679^{\circ}$ の範囲にある。

3)山居山

城下の南に位置する、なだらかな山容の山で、山頂（標高94. 4m） の他にピークが顕著な山居山 (東a)（標高 $103.6 \mathrm{~m}$ ) とピークが不明瞭 な山居山(東b) (標高84.9m)の二つが見通される。葬地であったこと を示す「サンマイ」という地名が残っていることや中世から麓に寺 町が形成されていること、領主内藤信輝が山居山の東端、牛沢で火 葬された史実から、共同墓所として利用されていたと考えられてい る。 ${ }^{19)}$ 山居山を対象山とする見通し街路は計12本で、これらの街 路の始点〈s〉からの仰角は2. $543^{\circ}$ から $9.194^{\circ}$ の範囲にある。

4) 熟瓷巣山

城下の東に位置する双耳峰で、山頂 (標高 $1093.3 \mathrm{~m}$ ) と中岳 (標高 1003. $5 \mathrm{~m})$ の明確な二つのピークが見通される。山頂に鎮座する鷲巣 権現は水神信仰の神、河内大明神を合祀する布部の山宮であり、神 体山として認識されていたことがわかる。注20)熟ヶ巣山を対象山と する見通し街路は計22本で、これらの街路の始点〈s〉からの仰角は $3.410^{\circ}$ から $3.886^{\circ}$ の範囲にある。

5) 鷹取山

城下の北に位置する鋭く尖った山容の山である。山頂 (標高 418. 8m) に祀られる奥院薬師如来は、水神信仰の神、河内大明神が鎮 座する宮の下の山宮であり、熟ヶ巣山と同様、神体山として認識さ れていたことがわかる。注21) 鷹取山を対象山とする見通し街路は計4 本で、これらの街路の始点〈s〉からの仰角は5.014 から6.669 の 範囲にある。

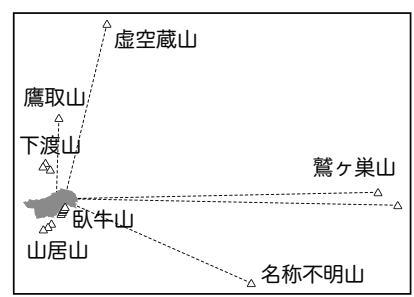

対象山位置

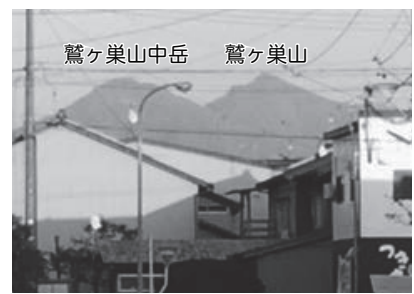

鷲ヶ巣山

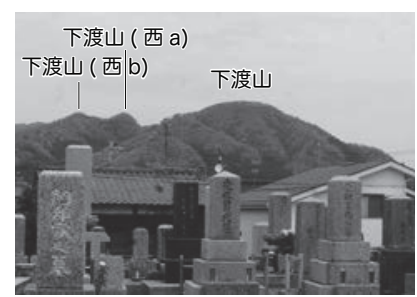

下渡山

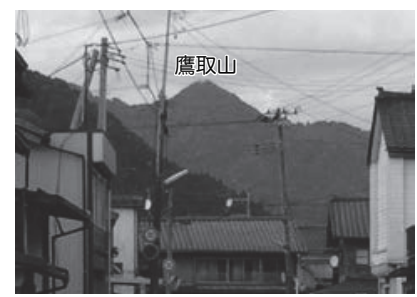

鷹取山

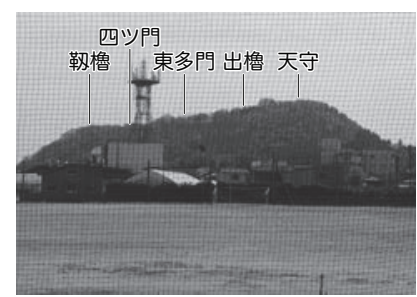

臥牛山

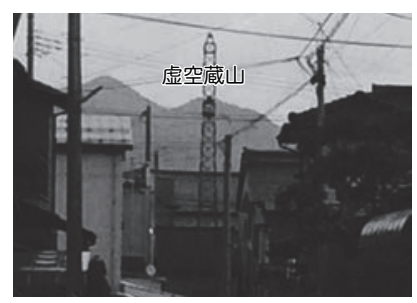

虚空蔵山

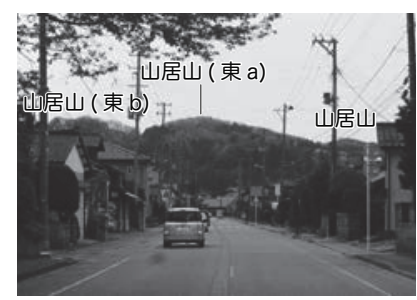

山居山

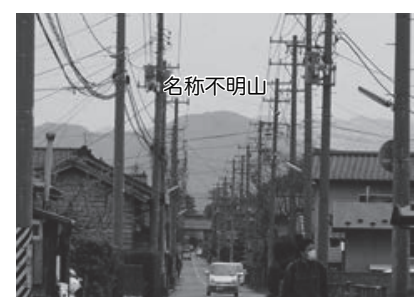

名称不明山

図 4 対象山の位置と形状及び目標物の分布 
2)ずれ型の見通し街路における山当てとヴィスタの実態(図5)

ずれ型は、村上城下の中心で大手道と直行する大手通りと呼ばれ た南北の街道軸と、城下縁辺の武家地に位置する。2a、2bは商店街、 旅籠街として賑わった大手通りの中心的な町人地である。両端部が 鍵型街路に接続したあと正面に見通しており、対象山の見え隠れの 風景が確認される。2c、2dは城下縁辺部の武家地に位置する。目標 物は、 $2 \mathrm{a} 、 2 \mathrm{~b}$ では南北に位置する山居山(東a)、下渡山を見通し、 $2 \mathrm{c}$ は天守、 $2 \mathrm{~d}$ は山居山(東b)を見通す。いずれも街路中心視点場の近傍 に位置する。ライン間角度は、 $1.103^{\circ}$ から $4.704^{\circ}$ の範囲にあった。 また、ずれ型は2cを除き全て平坦地に位置している。

3)ゆらぎ型の見通し街路における山当てとヴィスタの実態(図6) ゆらぎ型は、城下の骨格となる街路、東西の街道軸、城下縁辺部、 の三地区に位置する。まず、3a〜 $3 \mathrm{e}$ は、城下の骨格となる街路上に 位置する。3a、3bは新町のメインストリートであり、3aは秋葉門と 耕林寺門を結び、3bは袋門に接続する $3 \mathrm{a}$ と平行の骨格街路である。 両街路とも沿道を流れる水路によって㕍行するが、名称不明山を正 面に見通す街路中心視点場が多い。この部分でのライン間角度注26) は、0.069 から $1.004^{\circ}$ である。3c、3dは三の丸のメインストリー トである。この街路から眺められる山居山(東b) と鷹取山は、北部の 平坦地ではライン間角度 $0.596^{\circ} 、 1.162^{\circ}$ で正面に見通し、急傾斜 地に沿う南部では、ずれて見通す。3eは、袋門と秋葉門を結ぶ街路 で、堀に接する。堀の幅が細い東部ではライン間角度 $0.618^{\circ}$ で熟ヶ 巣山を正面に見通すが、太さの増す西部では、ずれて見通す。

$3 \mathrm{f} \sim 3 \mathrm{~h}$ は城下の中心となる東西の街道軸に位置し、職人の居住区 を含んだ町人地が連なる。これらは、微高地の形状に適合するよう

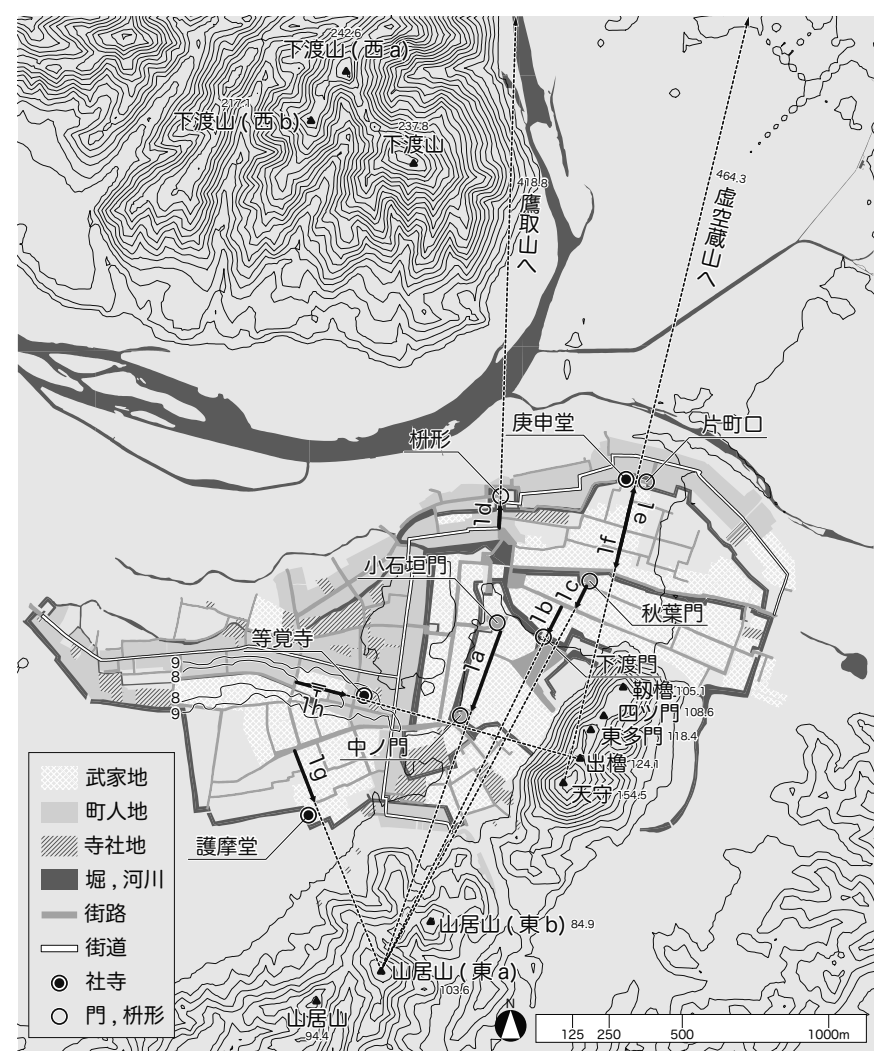

軸型の見通し街路 に配置されている。肴町口から順に、山居山(東b)、熟ヶ巣山中岳、 四ツ門を見通す。

残りの46本は、地形変化の激しい城下縁辺部に位置しており、内 37本に微地形との関係が確認できる。 $4 \mathrm{a} \sim 4 \mathrm{y}$ の街路は、微地形に沿 って湾曲する街路の一部で目標物を見通す。4a、4bは門前川の河川 堤防、 $4 \mathrm{c} \sim 4 \mathrm{q}$ は、微高地沿いの急傾斜地、 $4 \mathrm{r} \sim 4 \mathrm{y}$ は、微高地に挟ま れた窪地、に沿ってそれぞれ屈曲している。これらは東に位置する 熟ヶ巣山、臥牛山を見通す。一方、 $5 a$ 〜 51 は傾斜地を通過する街 路の一部に位置する。 $5 \mathrm{~d} 、 5 \mathrm{e} 、 5 \mathrm{k}$ を除き、全て傾斜地に隣接する微 高地に位置しており、周囲へ景観が開ける場所で目標物を見通す。 $\mathrm{s}-\mathrm{e}$ 間距離は、平均 $63.0 \mathrm{~m}$ で、全体平均 $138.4 \mathrm{~m}$ と比較して短い。これ らは、街路中心視点場近傍の下渡山、臥牛山、山居山を見通すもの が多い。

4) 曲折眺望型の見通し街路における山当てとヴィスタの実態 (図6) 曲折眺望型は、地形変化の激しい城下縁辺部に位置しており、寺 社地の $6 \mathrm{c}$ を除き、全て街道上に位置する。 $6 \mathrm{c} 、 6 \mathrm{~d}$ は傾斜地の直前で 屈曲し、坂を下りながら目標物を見通す。6f～6iは、堀と河川堤防 の形状に適合するように鍵型街路が配置されている。また、6jは微 高地の形状に合わせて屈曲している。 $\mathrm{s}^{-} \mathrm{e}$ 間距離は平均 $22.3 \mathrm{~m}$ と短い。 始点 $\langle\mathrm{s}\rangle$ での仰角平均は $6.8^{\circ}$ で、全体平均 $5.3^{\circ}$ と比べると、比較 的仰角の高い目標物を見通すことがわかる。

\section{4-2. 4類型と3つの分析軸との関係の考察}

以上のことから、4類型と $3 つ の$ 分析軸との関係を考察し、山当て とヴィスタの実態を述べる。

第一に、二の丸、三の丸、新町といった、城郭が立地する臥牛山

図 53 つの分析軸から見た軸型とずれ型の見通し街路における山当てとヴィスタの実態 

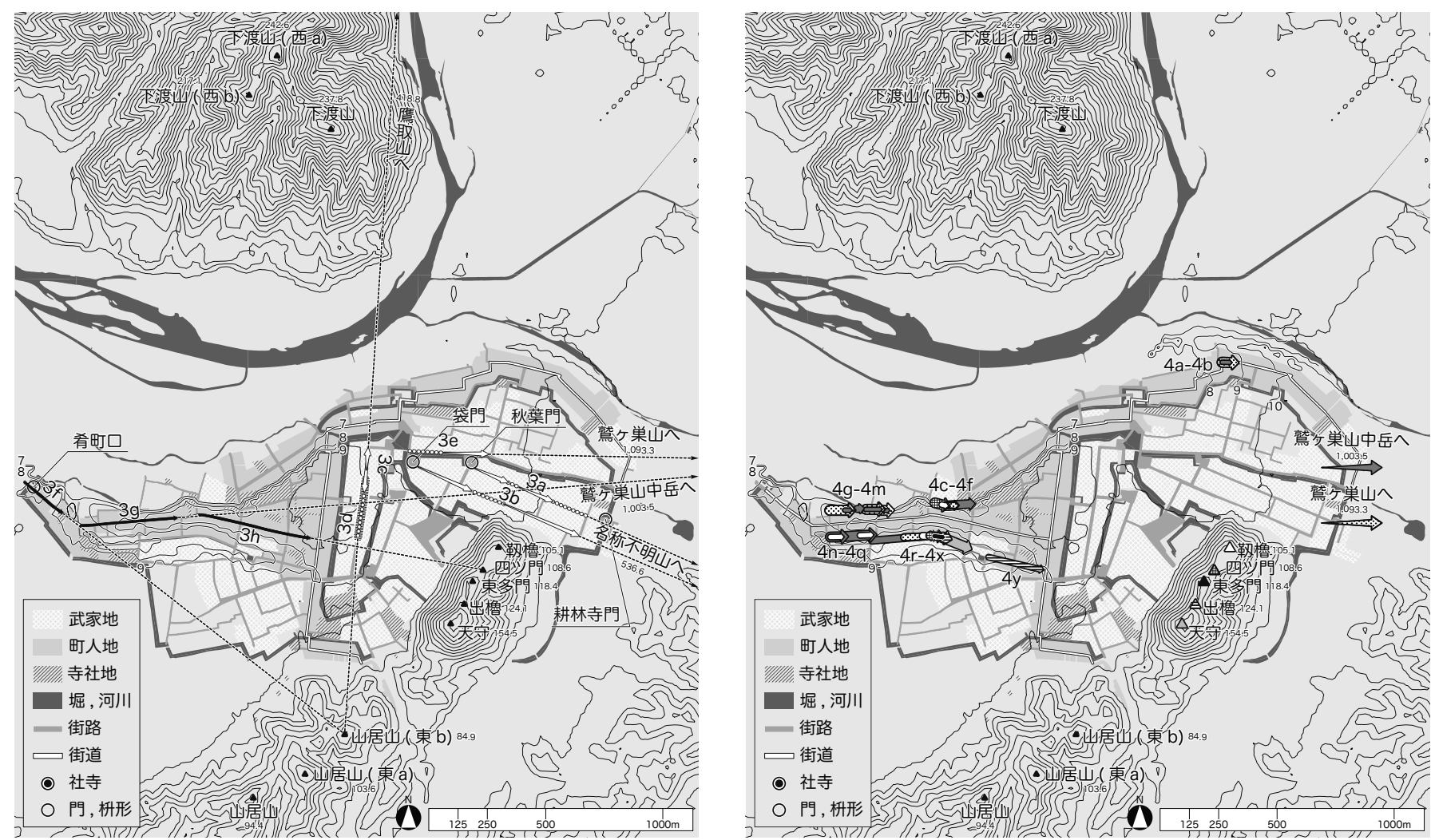

ゆらぎ型の見通し街路 A

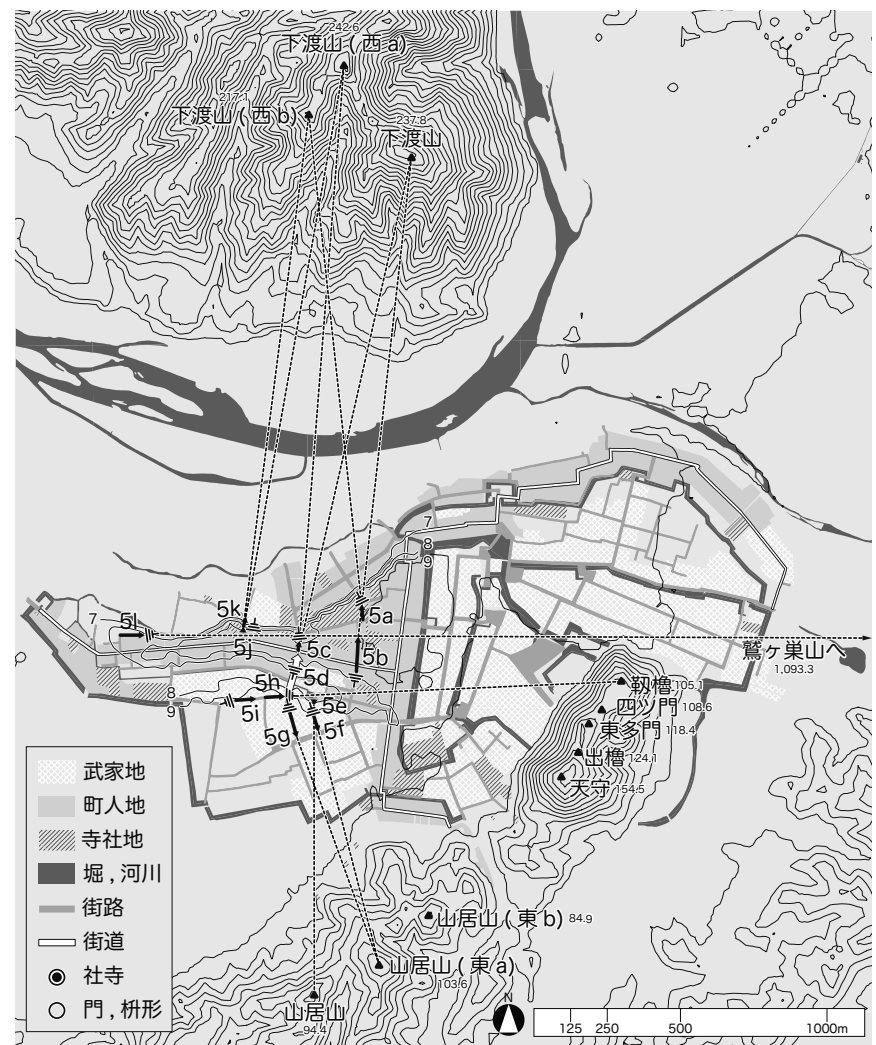

ゆらぎ型の見通し街路 C

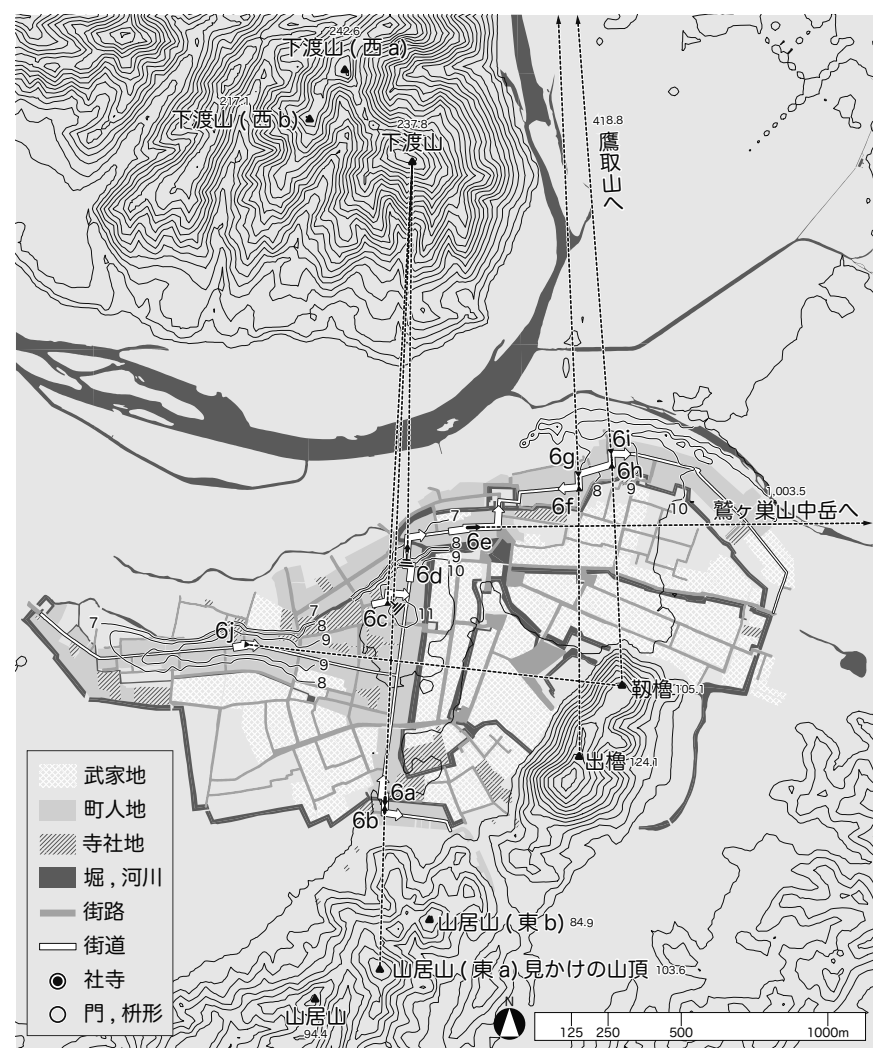

曲折眺望型の見通し街路

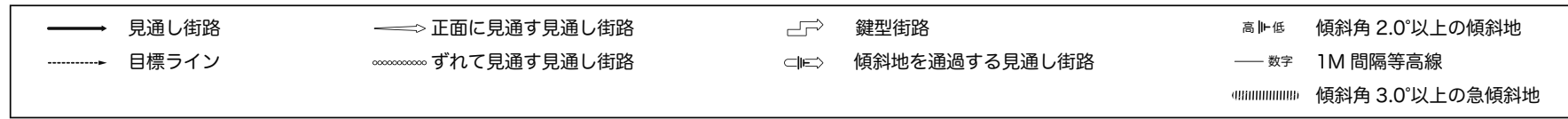

図 63 つの分析軸から見たゆらぎ型と曲折眺望型の見通し街路における山当てとヴィスタの実態 
麓の武家地で、城門同士を結ぶメインストリートなど、城下の骨格 となる街路では、軸型が1本、ゆらぎ型が5本確認された。軸型は、 ライン間角度 $0.664^{\circ}$ で目標物を正面に見通し、ゆらぎ型は、微地形 や水路の影響を受けて屈曲、雁行するものの、これらの影響が少な い部分では、その多くがライン間角度 $1.0^{\circ}$ 以下で正面に見通す。

第二に、南北の街道と重なる中心町人地では、両方向にずれ型が 確認された。街路中心視点場の近傍に位置する目標物がずれて見通 され、街路端部で鍵型街路に接続したあと正面に見通しており、対 象山の見え隠れの風景が確認されることがわかった。

第三に、地形変化の激しい城下縁辺部や、微高地上に位置する東 西の街道軸では、ゆらぎ型と曲折眺望型が確認された。ここで確認 されるゆらぎ型には、微地形の形状に沿って湾曲する街路と、傾斜 地に隣接する微高地に位置する街路がある。鍵型街路の屈曲の先や 傾斜地に隣接する微高地といった周囲への視界が開ける場所では、 街路中心視点場の近傍に位置寸る目標物や、仰角の高い目標物を見 通し、 $\mathrm{s}^{-} \mathrm{e}$ 間距離は短い。

第四に、社寺の参道や門及び妌形に接続する街路の多くで軸型が 確認される。対象山は、山頂の明確なものが多く、この中には、鬼 門鎮護を目的に片町口に移築された庚申堂の参道で鬼門鎮護の神が 祀られる虚空蔵山を見通せるなど、社寺と対象山に信仰上の関係が 確認されるものもあった。

\section{5. まとめ}

本研究では、GIS を用いて藩政末期と街路構成にほとんど変化の ない明治中期頃の市街地構成を復元し、山当てとヴィスタの実態を 明らかにした。GIS を用いることで、復元による正確な街路形状と、 移動に伴う目標物の位置変化を正確に解析することができ、現場の 目視では把握の難しい微細な景観特性の違いを明らかにした。ここ から、山当てとヴィスタを明確に類型化することができ、結果とし て、軸型、ずれ型、ゆらぎ型、曲折眺望型、の 4 類型を抽出した。 また、文献調查により街路の立地条件や対象山の意味を詳細に把握 し、GIS を用いた微地形の計測により、地形条件を正確に把握する ことができた。ここで得られた、街路の立地条件、対象山、地形条 件、を 3 つの分析軸と設定し、4 類型との関係を考察した結果、以 下の 4 点が明らかになった。

第一に、城下の骨格となる街路では、軸型とゆらぎ型が確認され、 軸型ではライン間角度が $0.7^{\circ}$ 以下で正面に見通し、ゆらぎ型では微 地形や水路の影響が少ない部分で、ライン間角度 $1.0^{\circ}$ 以下で正面に 見通す。

第二に、南北の街道と重なる中心町人地では、両方向にずれ型が 確認された。街路の両端部で鍵型街路に接続しており、対象山の見 え隠れの風景が確認された。対象山は、街路中心視点場の近傍に位 置する。

第三に、傾斜地や微高地など、地形変化の激しい場所では、ゆら ぎ型と曲折眺望型が確認された。ここでは、傾斜地に隣接する微高 地、鍵型街路の屈曲の先など、周囲への視界が開ける場所で、 $\mathrm{s}^{-} \mathrm{e}$ 間距離の短い見通しが確認された。この場合の多くは、対象山が街 路中心視点場の近傍に位置する山、仰角の高い山である。

第四に、社寺の参道や門及び柝形に接続する街路では山頂の明確 な対象山に対する軸型の見通し街路が確認された。中には、鬼門鎮
護を目的に片町口に移築された庚申堂の参道で鬼門鎮護の神が祀ら れる虚空蔵山を見通せるなど、社寺と対象山に信仰上の関係が確認 されるものもあった。

以上述べたように、目標物と街路の見通しとの関係や街路形状か ら、4つの類型を抽出し、それぞれの立地条件や目標物に関わる景観 の構成に、明確な特徴がある実態を明らかにした。しかし、これら が意図的にデザインされたと言うことはできず、また、全くの偶然と いうにはあまりにも明解な構成であるといわざるを得ない。著者ら の先行研究 ${ }^{1), 3,44}$ で、他の多くの城下町都市でもこのような実態は 観察できるが、これを文献により明らかにすることは今のところで きていない。宮本も指摘するように、注 27$)$ さらに資料的な精査が必 要である。しかし、築城、町割りの際に、明確な意図でなくても、周 囲の地理的条件や景観に導かれて、本論で示したような景観ができ あがったであろうことは、合理的な推定と考えることができると思 われる。

\section{謝辞}

この研究を進めるに当たって多くの方々のお世話になりました。 現地調査は、山田広良様、増子正臣様をはじめ、村上市役所の皆様、 村上市教育委員会の塩原知人様、村上市郷土資料館の桑原猛様、新 潟地方法務局村上市局の皆様のご協力を得て行いました。記して感 謝の意を表します。

\section{参考文献}

1）佐藤滋, 久保勝裕, 菅野圭祐, 椎野亜紀夫：GIS を用いた城下町都市に おける道路中心ラインと山頂の位置関係に関する検証一山形県鶴岡市を対 象として一, 日本都市計画学会都市計画論文集, 49-1 号, pp. $71 \sim 76$, 2014. 4

2) 久保勝裕, 安達友広, 菅野圭祐, 佐藤滋: 北海道の植民都市における「山 当て」の実態に関する研究 後志地方の 6 町村を対象として, 日本都市計 画学会都市計画論文集, 49-3 号, pp. 759 764, 2014. 10

3) 佐藤滋 : 新版図説城下町都市, 鹿島出版会, 2015

4) 佐藤滋: 城下町の都市デザインを読む 近世城下町のまちづくり手法の発 見，造景， No. $12 ，$ pp. 135 158，1997. 12

5）佐藤滋 : 城下町都市の近代都市づくり, 鹿島出版会, 1995

6）宮本雅明：都市空間の近世史研究, 中央公論美術出版, 2005

7）桐敷真次郎：天正・慶長・寛永期江戸市街地建設における景観設計, 都 市研究報告, 第 24 号, pp. 1 22, 1971.8

8）桐敷真次郎：慶長・寛永期駿府における都市景観設計および江戸計画と の関連, 都市研究報告, 第 28 号, pp. 1 31, 1972.1

9）桐敷真次郎：江戸のデザイン，建築雑誌， 91, pp. 1235〜 1236, 1976.12 10）高見僘志：近世城下町の設計技法 視軸と神秘的な三角形の秘密, 技報 堂出版, 2008

11）揚村固, 土田充義: 島津藩における麓集落に関する研究：街路設計手法 について, 鹿児島大学工学部研究報告, 33, pp. 209〜238, 1991.5

12）趙城埼, 佐藤滋: 景廊による都市の景観構造の記述に関する研究一山あて 景観を特徵とした近世城下町を基盤とした都市を対象として一, 日本建築 学会計画系論文集, 第 632 号, pp. 2165 2172，2008. 10

13）村上市・村上市教育委員会：越後村上城下町 伝統的建造物群保存対策 調査報告書, 村上市・村上市教育委員会, 1991

14）佐藤甚次郎：明治期作成の地籍図, 古今書院，1986

15）村上市教育委員会 : 史跡村上城跡整備基本計画,村上市教育委員会, 1998

16）村上市：お城山とその周辺整備基本計画，村上市，1992

17）西村幸夫: 平成 14 年度観光資源保護調査 村上の町家と町並夕景観, 財 団法人日本ナショナルトラスト，2003

18）村上市：村上市史別編絵図・地図、年表, 村上市, 2000

19）村上市：村上市史通史編 2 近世，村上市，1999

20）村上市：村上市史民族編下巻，村上市， 1990

21）村上市：村上市史別編絵図・地図、年表，村上市，2000 
22）村上市教育委員会：村上市史編さん資料第三号，村上市教育委員会市史 編さん室, 1987

注

注 1) 参考文献 1), 2)で同様に指摘した。

注 2) 2-1 で詳細に記述する。

注 3) 村上市・村上市教育委員会 : 越後村上城下町, pp. 10 17

注 4) 参考文献 14），p. 11 で、「旧土地台帳附属地図は明治前期に作成された もの、あるいはそれを土台にその後において補訂されたものである。それ は、土地台帳制の実施に備えて地租改正で作成された地図の不備を改良す るために、明治 18〜21 年に行った地押調査で調整された「更正地図」が主 体となっている。しかし、更正地図は必ずしも全府県にわたって調整され たわけではない。明治 6 14 年の地租改正事業で作成された地図の場合も、 この事業で新規に作成された府県が多いが、明治 5 6 年の壬申地券交付調 査で作成されたものを根底にしたり、継続して地図調整を行った府県も少 なくなかった。」と述べられている。

注 5) 新潟地方法務局村上市局において、村上旧城下域の三字 (大字村上字大 工町、大字村上字長井町、大字本町字三之町) について公図の資料調査を行 ったが、作成年代の記載がなかったため、明確に断定することはできない。 しかし、村上市遺跡整備室には、「村上更正図 (村上町・本町分) ( $\mathrm{S}=1 / 1200) 」$ が存在し、旧城下域の図面の多くには明治 4 年の注記がある。中には、修 正が加えられたものも存在するが、参考文献 14)の言説を参考にすれば、 明治 18〜21 年までには作られたと考えられる。公図と村上更正図は縮尺が 異なるため、同一のものではないが、調査図の赤道と更正図の比較を行っ たところ、市街地構成に異なる部分はなく、同時代に作成されたものと推 察できる。以上を踏まえ、本研究では、公図が明治中期頃までに作成され たと考え、分析を行う。

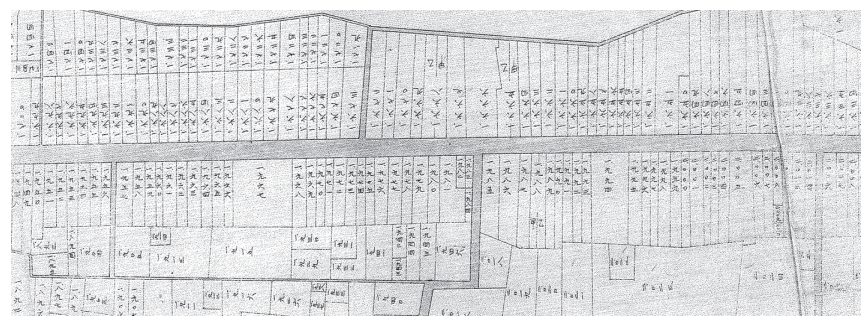

付図1 村上更正図 $(S=1 / 1200)$ 一部〈村上市遺跡整備室蔵〉

注 6)村上市 : 村上市史別編絵図・地図、年表, pp. 52 53

注 7) 比較して変化が確認される柝形と街路を、付図 2 の通り、内藤信民城主 時代の村上城下絵図上に示す。

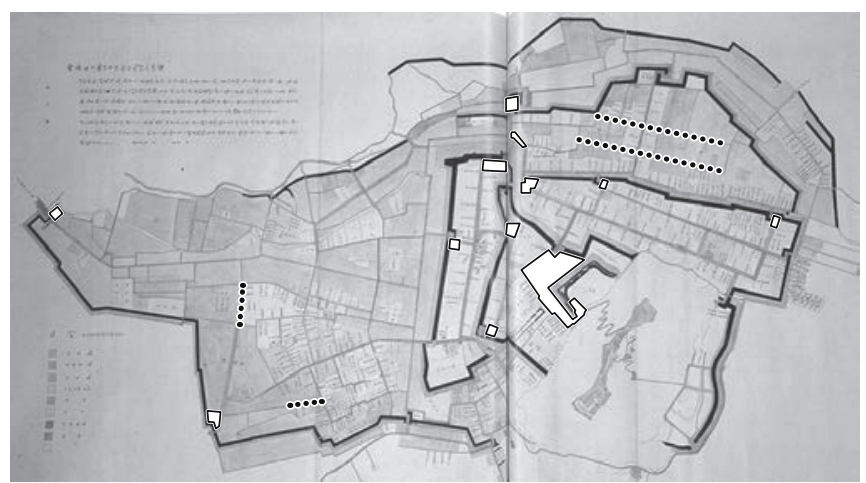

$\square$ 新設道路が通され、形状が変化している枅形

....... 形状に変化のある街路

付図2 内藤信民城主時代の絵図と公図との比較

〈村上市：村上市史別編絵図・地図、年表, pp. 52 53、内藤信民城 主時代村上城下絵図を基に作成〉

注 8) 周囲に視界が開ける枡形内部や街路形状が変化した街路でも、山当てや ヴィスタが確認される可能性があるが、GIS での正確な復元が出来ず、角
度等の計測が行えないため、本研究の分析対象から外した。

注 9) 地形学上の山頂については、参考文献 2)の特定方法を引用する。ここで は、「標高が最も高い地形学上の山頂の位置は、国土地理院の「測量の基 準点 (三角点座標)」を用いたが、「日本の主な山岳標高」に示された座標(山 頂座標）と比較し、両者が異なる場合は、資料調査等によって地形学上の山 頂の座標を特定した」とされている。

注 10) 村上市教育委員会 : 史跡村上城跡整備基本計画, p. 54

注 11) 各構築物高さの特定方法を以下に示す。天守、東多門、四ッ門につい

ては、参考文献 16)に記載の図面から高さ寸法を読み取った。勒櫓、出櫓 に関しては、城跡に一切の建物が存在せず、古文書にも、立面形状や規模 に関する記載がないが、正徳五年『村上御城廓』によると、靭櫓は二層、 出櫓は一層であったことがわかる。そこで、三層櫓である天守の寸法から それぞれ規模を推定する。勒櫓は天守の二層分の高さ、出櫓は天守の一層 分の高さを、参考文献 16)の図面から読み取り、それぞれの高さとした。 注 12) 西村幸夫 : 村上の町家と町並夕景観, p. 57

注 13) 仰角の算出方法を以下に示す。まず、藩政末期〜明治初期に存在した 町家の軒及び棟の高さと、道からの水平距離を、参考文献 17) より測定し、 計 7 戸の平均值、軒 : 高さ $4500 \mathrm{~mm}$ 、水平距離 $0 \mathrm{~mm}$ 、棟 : 高さ $6700 \mathrm{~mm}$ 、水平 距離 $6700 \mathrm{~mm}$ 、を得た。これを藩政末期〜明治初期に存在した一般的な町家 の寸法とした。次に、街路中心点を a、目標物をP、とし、a と P を結ぶ目 標ラインが軒と交わる点を $\mathrm{T}$ 、棟と交わる点を $\mathrm{U}$ とする。最後に、国土地 理院発行の「数值標高モデル JPGIS (GML) 形式 $5 \mathrm{~m}$ メッシュ」から a、T、U それぞれの最近傍点の数值を読み取り、a は視線高さ $1500 \mathrm{~mm}$ を、T は軒高 さ $4500 \mathrm{~mm} 、 \mathrm{U}$ は棟高さ $6700 \mathrm{~mm}$ を足し合わせて標高とする。

(1) 目標物 $\mathrm{P} \sim$ の仰角 $\beta_{\mathrm{P}}\left({ }^{\circ}\right)=\tan ^{-1}\{\mathrm{a}-\mathrm{P}$ 間標高差 $(\mathrm{m}) / \mathrm{a}-\mathrm{P}$ 間距離 $(\mathrm{m})\}$

(2) 軒 $\mathrm{T}$ への仰角 $\left.\beta_{\mathrm{T}} \mathrm{C}^{\circ}\right)=\tan ^{-1}\{\mathrm{a}-\mathrm{T}$ 間標高差 $(\mathrm{m}) / \mathrm{a}-\mathrm{T}$ 間距離 $(\mathrm{m})\}$

(3) 棟 $\mathrm{U} \sim 0$ 仰角 $\beta_{\mathrm{U}}\left(^{\circ}\right)=\tan ^{-1}\{\mathrm{a}-\mathrm{U}$ 間標高差 $(\mathrm{m}) / \mathrm{a}-\mathrm{U}$ 間距離 $(\mathrm{m})\}$

注 14）ライン間角度の定義と計測方法については、参考文献 1),2)で詳細に示 した。ライン間角度は、街路中心線上からの目標物座標の位置的なずれを 定量的に検証するもので、絶対值が小さい程、より正面に目標物を見通す ことを示す数值である。ここでは特に、二つの隣接する街路中心点を結ん だ線と、目標物から遠い街路中心点から引いた目標ラインとの角度差をラ イン間角度として測定した。

注 15) 町人地以外では、建物が後退して配置されているため、見通しを遮る 要素が少なく、実際には仰角が高い目標物の多くを借景的に見通すことが できる。しかし本研究では、町人地の詳細な分析で特定されたずれ型のラ イン間角度最大值 $4.704^{\circ}$ を参考に、 $5^{\circ}$ 未満とすることで、街路上からの 軸的な見通しのみを分析の対象とする。

注 16) 非直線見通し街路で湾曲が急な場合、 $\mathrm{s}^{-} \mathrm{e}$ 間距離が短く、始点 $\langle\mathrm{s}\rangle$ か ら終点〈e〉まで目標物がずれることなく正面に見通される街路も存在する。 しかし、これらにおいても、移動する際、正面の範囲内で目標物位置が大 きく変化して見通されるため、ゆらぎ型に分類する。

注 17)村上市：村上市史別編絵図・地図、年表，p. 25

注 18 ) 村上市 ・ 村上市教育委員会 : 越後村上城下町, pp. $10 \sim 17$

注 19)村上市：村上市史通史編 2 近世，p. 246

注 20) 村上市：村上市史民族編下巻，p. 283

注 21) 同上, pp. 290 292

注 22) 村上市教育委員会 : 村上市史編さん資料第三号, p. 51

注 23) 三角点座標や山頂座標が設定されておらず、地域で共通の呼称もない 名称が不明な山を「名称不明山」と称する。

注 24) (1)街道や大手道といった主要街路との位置関係、(2)城門や社寺といっ た構築物との位置関係、(3)土地利用及び城下の中心部か縁辺部かの違い、 (4)街路の名称や城下域での位置付け、の 4 点から特定を行った。

注 25) 村上市：村上市史民族編下巻，p. 325

注 26)ゆらぎ型見通し街路においては、全ての街路中心視点場から、目標物 を正面に見通すか、ずれて見通すかを確認した。ここでは特に、連続して 正面に見通す街路中心視点場の始点と終点を結ぶ線と、始点からの目標 インとの角度差をライン間角度として測定した。

注 27) 宮本は、参考文献 6)，p. 274 において、「城郭の特定部分をヴィスタ の目標とした街路設定によって空間設計が実施された事実が文献史料と遺 存街路および遺構の両面から確認されると、他にも同様に主要街路や水路 と城郭とがヴィスタによる関係を結びつつ空間設計が行われた城下町を、 遺存街路と遺構を復元的に検討して探ることが可能となってくる。」と述 ベている。 
The Japanese castle towns today appear in Nature; the castles and their surrounding mountains provide multiple views and vista with disappearing yet visible Donjon and Turret and several mountain peaks nearby. Such urban design thinking integrates built environment into Nature as one. All this, nevertheless, remains hypothetical. The intention to mingle man-built environment with Nature seems unconvincingly. Thus, detailed analyses of Yama-ate and Vista await us for objective results.

Here aims to manifest the sequence of vista; viz., from various view-spots and from the street axis people see multiple sceneries. Murakami City is selected, for its being one of the most verifiable castle towns; this team tries to analyze the interaction between the scenery's peculiar characters and their locational conditions by GIS with the following.

First, this team discovers some mid-Meiji traces from the urban composition - as intact as that of the Feudal - and plans to restore the street patterns back to mid-Meiji, and the Donjon, Turret and mountain peaks as objects visible in Yama-ate and Vista (objects henceforward). Additionally, the team measures micro-topography.

Second, specify the streets of unobstructed views in sequence for these objects, and conclude four types basing upon street patterns and upon how the visible objects appear in the pedestrian courses. Still, the character of Object Mountain with objects must be grasped.

1. Axis type: straight streets with objects visible along the axis.

2. Tilted type: straight street with objects with tilted semblances visible from the street.

3. Fluctuation type: non-straight streets synthetic of Axis and Tilted. Walking from the start to the end, people face objects directly, and while walking, these objects keep changing their appearances owing to the tilted axis from different street locations.

4. View-turning type: along the key-shaped street, a new visual field opens at the end of curvature; the objects turn, twist and appear in the unobstructed perspective.

Third, each type of unobstructed views in sequence is analyzed under three points: 1) street location, 2) object mountain, 3) topography condition. The following four characters of Yama-ate and Vista can become manifest.

(1) The town's main street, as framework, must be verified as Axis and Fluctuation types. In measuring the angles between extended street center line and line toward the objects, the unobstructed view of Axis Type has less than $0.7^{\circ}$ difference and certain area of the Fluctuation Type, without influence from micro-topography and water way, takes the view by detaching from the viewpoint field by $1.0^{\circ}$ and has the same view as the straight street.

(2) The street that runs through the central townsman's area is tilted and overlaps the south-north highway, and both ends connect the key-shaped street, while the object mountain, observing from the street, is appearing and disappearing. The location of Object Mountain is nearby the visual field.

(3) The topography with violent elevation change is either Fluctuation or View-turning type. In such cases, the micro plateau adjacent to the slopping land or the end of the bending key-shaped street, the field of vision opens to the periphery with short-distance unobstructed views. In most cases, if an object mountain is close, the angle of elevation is high.

(4) The street that connects the entrance path of Shrine or Temple, or even the gate square of castle town is usually verified to be the Axis Type to specific mountain top. One particular character is noticed; owing to belief, the defense of Buddhist doctrines is built on the Axis street and the same defense would also be built for guarding the Ghost Gate on the mountain top in line with the axis. 